\title{
Gender and forum shopping in land conflict resolution in Northern Uganda
}

Anying, Irene Winnie; Gausset, Quentin

Published in:

The Journal of Legal Pluralism and Unofficial Law

DOI:

10.1080/07329113.2017.1383023

Publication date:

2017

Document version

Publisher's PDF, also known as Version of record

Citation for published version (APA):

Anying, I. W., \& Gausset, Q. (2017). Gender and forum shopping in land conflict resolution in Northern Uganda. The Journal of Legal Pluralism and Unofficial Law, 49(3), 353-372.

https://doi.org/10.1080/07329113.2017.1383023 


\section{The Journal of Legal Pluralism and Unofficial Law}

\section{Gender and forum shopping in land conflict resolution in Northern Uganda}

\section{Irene Winnie Anying \& Quentin Gausset}

To cite this article: Irene Winnie Anying \& Quentin Gausset (2017): Gender and forum shopping in land conflict resolution in Northern Uganda, The Journal of Legal Pluralism and Unofficial Law, DOI: 10.1080/07329113.2017.1383023

To link to this article: http://dx.doi.org/10.1080/07329113.2017.1383023

$$
\text { 曲 Published online: } 28 \text { Sep } 2017 .
$$

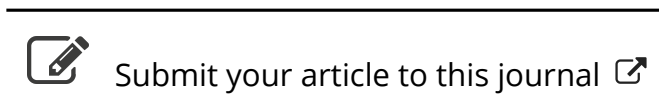

\section{LIIl Article views: 19}

Q View related articles ๘

View Crossmark data ¿ 


\title{
Gender and forum shopping in land conflict resolution in Northern Uganda
}

\author{
Irene Winnie Anying ${ }^{\mathrm{a}}$ and Quentin Gausset ${ }^{\mathrm{b}}$

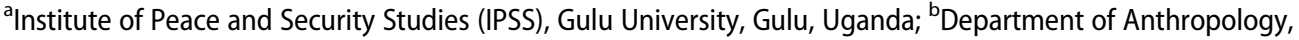 \\ University of Copenhagen, Copenhagen, Denmark
}

\begin{abstract}
Northern Uganda has been plagued by a long and violent civil war that lasted from 1996 to 2006, during which 2.5 million people were internally displaced and placed in camps. During the conflict, Uganda adopted a new constitution and a new land act that recognised customary land tenure and the role played by customary institutions in resolving land disputes. Following the cessation of hostilities in 2006, people began to go back "home", and many land conflicts ensued. Because women are generally considered as particularly vulnerable in land conflicts, they have received much attention from the Ugandan government, international donors, and NGOs. This article focuses on how women make use of the existing legal pluralism in Uganda to defend their interests in land disputes. It argues that land conflicts are often proxies of social conflicts, which play a major role in women's opting for customary institutions to resolve their land conflicts.
\end{abstract}

\section{ARTICLE HISTORY}

Received 2 December 2016

Accepted 19 September 2017

\section{KEYWORDS}

Legal pluralism; forum shopping; gender; Northern Uganda; Acholi; land conflicts

\section{Introduction}

Northern Uganda has been plagued by a long and violent civil war during which 2.5 million people were internally displaced and placed in camps. During the conflict, Uganda adopted a new constitution and a new land act, that recognised customary land tenure and the role played by customary institutions in resolving land disputes. When the cessation of hostilities agreement was signed in 2006, people began to return "home", and many land conflicts ensued.

Because women are considered as particularly vulnerable in land conflicts, they have received much attention from the Ugandan government, international donors, and nongovernmental organisations (NGOs). This article focuses on how women make use of the existing legal pluralism in Uganda to defend their interest in land disputes. It first introduces the concepts of legal pluralism and forum shopping, and discusses the advantages and disadvantages commonly associated with them. It then presents the historical and social context for land conflicts, with a special focus on gender, and compares how statutory and customary laws and institutions deal with them. Finally, it maps the different institutions that are part of forum shopping, and discusses two extended cases that illustrate 
how women use forum shopping strategically to further their interests. We argue that forum shopping might benefit women, especially when land conflicts are proxies of social conflicts.

\section{Legal pluralism and forum shopping}

Legal pluralism generally describes a situation in which two or more laws, legal systems or normative orders coexist (Michaels 2009, 245; Griffiths 1986; Woodman 1998; Rouland 1994; Vanderlinden 1989; Moore 1978, 57). Legal pluralism sees the existence of more than one legal order as resulting from the fact that human activity takes place in a multitude of social fields (Moore 1973) or social networks (Vanderlinden 1989), each of which generates and enforces its own rules. As a result, individuals are subject to as many regulatory orders as social fields or networks as they participate in.

Legal pluralism may arise where the state, through legislation, acknowledges and allows different bodies of religious laws or customary laws to be accommodated within the state institutional framework (Griffiths 1986; Woodman 1998). Legal pluralism may also occur as an empirical reality in which informal normative authorities regulate behaviour in a given society and coexists de facto with formal law, independently of whether a state gives them official recognition or not (Griffiths 1986; Woodman 1998). Generally therefore, in situations of plurality, individuals or groups find themselves presented with the possibility of options between and among those various normative orders and legal systems that are recognised within the normative framework of the state and those that exist de facto outside of any formal recognition. In the present paper, we distinguish between the formal State court system, that works with magistrates and that passes judgement on who is right and who is wrong, and alternative or informal fora comprising any forum that is not a State court (including local councils, traditional authorities, government officials and NGOs), that have no authority to pass judgements and that focus on mediations.

Disputants choose between co-existing normative orders and institutions, according to the constraints they face and the outcome they hope to achieve in different arenas. This propensity has been described as "forum shopping" (Benda-Beckmann and von BendaBeckmann 2010, 175; Whytock 2010; Juenger 1988, 554; Benda-Beckmann 1981, 171). The choice of one forum is not only made according to preferences for certain legal principles, but can also depend on non-legal differences such as physical and financial accessibility and impartiality, or cultural preferences based upon both cultural and legal traditions (Whytock 2010, 485; Benda-Beckmann 1981, 117).

Legal pluralism and forum shopping come with both challenges and opportunities. On the one hand, legal pluralism is regarded as detrimental to women's rights, because of the widespread view that customary institutions are procedurally biased and discriminate against women (Chopra and Isser 2012, 339; Corradi 2011, 2; Chirayath et al. 2005). Women are for example excluded from the dispute resolution process, the panel of adjudicators being composed exclusively of old men (Wehrmann 2008). Khadigala notes that local customs can defy women's rights with impunity and may have disempowering implications for rural African women and their claims to resources (Khadigala 2001). Moreover, the possibility of bringing cases simultaneously or successively in a variety of fora can serve a dilatory purpose and delay justice, or even bias it, because powerful actors dissatisfied with the outcome of justice in one forum can bring their case to other fora 
until they are satisfied, or until they exhaust the means and patience of their opponent (Spiertz 2000, 191; Chopra and Isser 2012). Thus, since power often plays out strongly against women, forum shopping has been seen to work to the disadvantage of women, because the powerful (usually men) tend to choose a forum that will determine the outcome at the expense of the vulnerable who are able to exploit only a limited number of opportunities (Chopra and Isser 2012, 353; Adoko and Levine 2009). This manipulation by the powerful is perceived to water down the advantages that arise from the possibility of choice created for disputants, but also from the possibility for the fora involved in dispute resolution to collaborate and complement each other (Kobusingye, Van Leeuwen, and Van Dijk 2016).

On the other hand, in many developing countries as well as in post-conflict situations, legal pluralism is deemed to increase access to justice since the absence of formal courts is compensated by the services provided by local institutions of dispute processing (Corradi 2011, 2; Wojkowska 2006; Barrera 2015, 6; Chopra and Isser 2012). Because formal state justice is not always accessible to the majority of people, informal systems can thus act as an alternative. In addition to their inaccessibility, some of the formal justice systems are also dysfunctional, most particularly in post-conflict or fragile states (Barrera 2015, 7; Chopra and Isser 2012, 449). Because these systems are faced with huge case backlogs, cases usually take a very long time to get resolved (Barrera 2015, 7). Backlogs works to the disadvantage of the vulnerable, who often have to contend with long geographical distances from their homes to the formal courts and bear the financial burden of travel costs, as the formal resolution of cases is often postponed.

By contrast, some authors argue that informal justice systems are more accessible because they are closer to people's lives and culture, are built on local norms and local conceptions of justice, have a high legitimacy, are process-oriented, and are cost-effective (Kindi 2010, 9; Levine and Adoko 2006; Rugadya 2008; Wojwoska 2006, 1; Stevens 2000).

Generally, when disputants have active choices, they can navigate between plural options. Their legal preferences arise from their socio-political situation and their assessment of where they are likely to get the best outcome (e.g. Basu 2012; Corradi 2011; Khadiagala 2001; Rao 2007; Chopra and Isser 2012, 353). Many women begin with more accessible and less costly community or customary fora, and progress to the formal courts system only if they fail to get a satisfactory outcome (Domingo and O'Neil 2014, 25). But they can also iterate between fora by moving from community forum to court and back again to the community, or by making claims in several fora simultaneously in order to increase their bargaining power (Domingo and O'Neil 2014, 25). Case studies on women's disputes to protect and advance their marriage and land rights illustrate the variety of ways through which women combine and navigate between different legal systems, combine individual rights drawn from formal and informal norms, and use different legal forums in strategic ways (Griffiths 1996; Hirsch 1998).

Social and economic resources play a major role in women's choices, however, and the possibilities for women to forum shop should not be overestimated. Because access to the formal justice system is costly and therefore restricted to those having substantial financial means (Griffiths 1996; Corradi 2011), women rely primarily on customary institutions to solve their problems. When women do seek remedy outside of the community, hybrid and/or specialised Alternative Dispute Resolution (ADR) fora are preferred over formal court systems, because these hybrid institutions have the benefit of their public authority 
in addition to being more affordable, physically closer and less intimidating than state courts (Rao 2007; Leonardi et al. 2010, 11-14; Domingo and O’Neil 2014, 25). But even though women do not directly challenge cultural or religious norms, they nevertheless creatively frame their claims within the combination of statutory and cultural or religious norms (Hirsch 1998). Thus, the coexistence of formal law side-by-side with customary law can contribute to improving women's situations, even though women rely mainly on informal institutions to solve their disputes (Corradi 2011).

This paper explores how legal pluralism and forum shopping are used as tactics that benefit women in Northern Uganda. Based on empirical data that we present below, we agree with Tanja Chopra and Deborah Isser $(2012,352)$ that customary systems are neither essentially good nor bad for women: it depends on how they are interpreted and applied. As a consequence, the implementation of women's rights requires engaging with legal pluralism rather than seeking to hasten its end (Chopra and Isser 2012, 352). We also agree with Corradi $(2011,24)$ that "given the role of non-state justice in producing and reproducing gendered relations, interventions need to engage with these too". Further, we adopt Helium's view that sees women as agents of change who mobilise different strategies of action in negotiating and securing their rights (Hellum 2000, 639).

We argue that in Northern Uganda, women can and actually do strategically use legal pluralism and forum shopping to their advantage. To bolster our argument, we present and discuss concrete case studies in which women rely on different and competing legal institutions to solve their problems. The cases that we discuss all relate to conflicts concerning customary land in the Acholi sub-region. In our discussion, we do not understand forum shopping as simply a binary choice between a statutory and a customary legal system, but rather as a choice between a wider range of different legal actors and institutions.

\section{Legal pluralism in Uganda}

In Uganda, legal recognition is given to customary law as well as customary law institutions. Article 237 of the Constitution of 1995 officially recognises customary land tenure as a form a legal tenure, and Section 3 of the Land Act specifically describes customary tenure as a tenure that is managed according the norms and customs of a particular community. Section 88 of the Land Act mandates that the traditional institutions can either determine or mediate over customary land disputes. It specifically provides in sub section (1) that; "Nothing in this Part shall be taken to prevent or hinder or limit the exercise by traditional authorities of the functions of determining disputes over customary tenure or acting as a mediator between persons who are in dispute over any matters arising out of customary tenure." In addition to officially recognising traditional authorities, the Local Council Court Act of 2006 gives the Local Council Courts unlimited mandate to deal with disputes in respect to land held under customary tenure (3rd schedule to Local Council Court Act 2006, Laws of Uganda, Section 10(e). Thus, Ugandan laws organise a system of legal pluralism that comprises the formal court system, the Local Council Courts and the Traditional Institutions. In addition to the three official categories mentioned expressly within the Land Act, there are also a number of other channels that participate in land dispute management, such as NGO or elected and appointed government leaders from the lower administrative unit at sub county level to the higher administrative unit at the 
District Level. However, these channels are not mandated by law to resolve land disputes, and their involvement is therefore informal.

All of these formal and informal institutions are mandated by law and do apply customary law in the determination of all matters relating to customary land tenure in as far as the customary norms applied do not contradict the constitution or deny women, children, and persons with disabilities access to customary land, or violate their rights to equality under the Constitution. The choice of law is forum-neutral and uniform across all fora, with the choice of forum having no effect on the substantive law applied. However, the Land Act is silent about the collaboration between the traditional institutions, the Local Council Courts and the formal magistrates Courts. The implication of this is that a dispute can be brought before the magistrates court, a local council court and before traditional institutions at the same time, without these systems knowing what is taking place before the others.

\section{Historical and social background to land conflicts in Northern Uganda}

Land has become a very sensitive issue in Northern Uganda since the end of the civil war in 2006. The civil war began in the mid-1980s and was characterised by a high level of violence. Approximately 60,000 to 100,000 children were abducted and used as child soldiers, porters, or "wives" of the Lord Resistance Army (LRA) soldiers, more than 100,000 people were killed, and about 2.5 million civilians were displaced by the war (United Nations 2013). At the height of the conflict, about 90 per cent of the population of Northern Uganda was displaced in camps, where living conditions were appalling (Dolan 2009). The first displacement of people goes back to the beginnings of the conflict, but in 1996, the state officially forced people to leave their homes and to stay in internally displaced camps that were protected by the army.

In 1995, the new Constitution acknowledged for the first time customary land tenure as a legal form of tenure. The new Land Act, passed in 1998, confirmed this and provided details on how customary land could be owned. In practice, the law acknowledges the customary usage of land and prevents state expropriation of such land. But at the same time, it declares that any vacant public land be held in trust by the State, which prevented the expansion of the Acholi population to vacant areas. Because the new Constitution and Land Act were passed while most of the population of Northern Uganda was living in camps far from their customary land and forbidden to farm beyond a radius of $2 \mathrm{~km}$ around the camps, these new laws were not integrated into state practices until after the cessation of hostilities in 2006.

Once peace was secured, more than 2 million Internally Displaced Persons (IDPs) who had lived in camps for 10-20 years, went back "home". This return phase was characterised by a high number of land disputes. The land had not been farmed for 10 years. Boundaries between fields had disappeared and had to be re-established. Many people had died during the war and land inheritance issues had been pending for a long time. All land inheritance cases had to be solved at once when people began to return home. Moreover, because there had been different phases of displacement with some people forced to move to a new place for a few years only to be displaced again into camps, people did not always know exactly where they had to return to when they were asked to "go back to where they came from before displacement". All this created many land disputes. 
Traditional leaders, who used to solve these conflicts before the war, now faced new challenges during the return period. Some elders had died during the war and their knowledge of land history and boundaries disappeared with them. Traditional leaders had also lost much of their authority during the displacement into camps. Part of their authority had rested on the ownership of cattle, but they had lost all their cattle during the war. Food relief in camps was distributed by women, which further weakened the authority of elder men. Life in camps was characterised by an extremely high density of population; in this kind of "urban" life, the traditional norms and social control mechanisms that once accompanied life in rural areas were weakened. According to Branch $(2008,10)$, "Acholi elders and chiefs have largely lost their power of social regulation, their role of mediating conflicts, and their political leadership role". These elders and chiefs today are in a weaker position to solve land conflicts than they were before the war, although they seem to be regaining some of their lost power in recent years.

Traditionally, land conflicts often accompany social conflicts. Jealousy between cowives, witchcraft accusations within the family or among neighbours, disagreements between brothers, husbands, and wives, widows and brothers in-law, or mothers-in-law and daughters-in-law, create social tensions that can easily translate into land conflicts. When it is difficult for family members or neighbours to live peacefully in the same location, confiscating the land of an opponent is a common strategy to force him or her to move elsewhere, which puts a definitive end to the social dispute. Access to land requires peaceful cohabitation with those who border or share this land, and as soon as social conflicts erupt, sharing land becomes problematic. Old agreements can be re-evaluated and eventually cancelled, which forces people to move elsewhere to find new land. It is therefore primarily people with fractured family relations that face problems accessing and securing land (see also Branch 2007, 36).

All these traditional conflicts reappeared when people started moving back to their home areas after the end of the war in 2006. But something changed during the war that had added another dimension to land conflicts: land commoditisation. Before the war, land was not seen as a commodity in Northern Uganda. It was not acquired with money but by hand power (clearing vacant land) or through social relations (people controlling a huge chunks of land would give a piece of their land for free to newcomers who were asking for it). During the war, however, land suitable for farming surrounding IDP camps was very rare and in high demand, and was rented out for a high price. Land thus began to be commodified.

Moreover, at the end of the conflict, IDPs were sensitised to the value of land, which was the only remaining capital left to the Acholi after they had lost all their cattle and material belongings during the war. Furthermore, the new Land Act contributed to changing people's perception of land by allowing them to own land customarily and by closing the old ways of expanding into vacant land. There were a few cases of highly controversial "land grabs", such as the famous "Madhvani" land deal, in which the Ugandan Government leased 40,000 hectares (ha) to an Indian multinational company in Amuru district to produce sugar cane (see, for example Barnabas 2013; Martiniello 2015; Stickler 2012). Such cases began to convince people that land had now become a commodity. The combination of all these aspects triggered a massive scramble for land as soon as people began to return home. Today, land has become equated with money, and everyone is looking for ways to control as much land as possible before it falls under someone else's control, which triggers both land conflicts and forum shopping. 
Land speculation and land conflicts are especially strong in the areas gazetted to become new urban centres, such as in Amuru. Since the compensation paid by the government to buy land for roads or public buildings in the new urban areas can be six to seven times higher than for adjacent land that is not part of the urban plan, there are many opportunities for people who are strategically located and able to grab the land of their neighbours in order to enrich themselves quickly. It is often people who were given land before the war who are the target of attempted "land-grabs": they are told that they do not belong to the locality and should go back to their "home area" and use their clan's land. This form of "patrilineal fundamentalism" (Whyte et al. 2013) thus impacts on the legitimacy and permanence of the gift of land made in previous generations in order to seize land that has now acquired a monetary value. Moreover, since there were few proper marriages during the war (cattle had been lost and the bride price could not be paid), and since many children were born out of wedlock, the clan affiliation of many people is now dubious. This can be used as an argument to refuse to give land to people with questionable pedigrees. Widows are also sometimes denied the right to stay on their husband's land, even though this is a clear contradiction of customary law (Whyte et al 2013). From some of the cases that we have followed, we can conclude that even when customary law and customary leaders do acknowledge the right of widows and long-term occupants to continue farming the land that they used before the war, their rulings are not always sufficient to deter land speculators from occupying and eventually selling land that (according to customary rights gained through past occupancy) is not theirs.

For the past 10 years, land conflicts have been on everyone's lips in Northern Uganda and have attracted a lot of attention from government, politicians, the media, NGOs, donor agencies, religious leaders, and researchers (Hopwood and Atkinson 2013, 17). The Trustland research project to which we are attached reflects this increased interest in land conflicts in the region. Women tend to be portrayed as victims in such land conflicts, both by researchers and by NGOs. In the Lango region of Northern Uganda, for example, LEMU (2009) reported that:

most widows and almost all divorced women face land rights violations. (...) Widows face several threats to their land. Often, their in-laws simply take over the land, and many widows do not have the physical strength to resist. Clan authorities tell themselves and others that they protect widows well, but in practice they often side with the land grabbers (the in-laws), or they may simply ignore the case. Where they do rule in favour of the widow, the in-laws may simply ignore their decision, and nothing is then followed up.

Gray and Kevane (1999) concur with this grim picture, and argue that it is not limited to Uganda but generally occurs throughout the continent. In a review of the situation of women's land rights in Sub-Saharan Africa, they argue that:

when land becomes scarce or rises in value, or when rights are formalized through titles or registration (...) Men use their position of dominance to "expropriate" women's rights to land. Women, whose rights to farm a plot of land were guaranteed by marital or kinship status, lose these rights and face a diminished access to land which underlies and reinforces a greater economic and social insecurity. The literature on women's access to land is replete with examples of these often dramatic reductions in rights (Gray and Kevane 1999, 17).

Even when women have become empowered as a consequence of life in the IDP camps, such as in Northern Uganda, this is seen as too good to last and almost always to their 
disadvantage - the higher they rise, the harder they may fall. For example, Branch claims that during the period of forced displacement to towns, "women, and to a lesser extent youth, have seen their authority and status rise precipitously in town", a change that he sees as "nothing short of historic" (Branch 2008, 10). But he also believes that: "Although firm adherence to patrilineal and patrilocal norms has been disrupted at present as a result of the war and displacement, this only increases the potential negative impact of their purposeful re-imposition by male authorities upon women and youth" (Branch 2008, 16).

While we agree that women have indeed less to say than men in customary land management in Northern Uganda and that this is a form of discrimination, we nevertheless believe that portraying women as perpetual victims of men's greed and violence is a cliché that hides a more complex picture. The more complex and comprehensive picture can only be understood by talking to all parties in a conflict instead of talking to women only, as is often the case in reports and articles systematically presenting women as victims. In our experience, when women's rights are challenged in a land conflict, it can be due to other women with whom they have a social conflict. Even when a land conflict involves people of both genders, women are sometimes on the side of the claimant who is trying to "dispossess" a man. In any case, our research and the case studies discussed below show that women are not totally powerless and are not always on the side of the losers. Women do have statutory and customary rights as well as strategies to assert these rights and win their case, a point that is also acknowledged by Gray and Kevane $(1999,17)$ :

Women, like men, are responding to reduced access by manipulating meanings underlying rights, by changing the incidence of exercise of rights, and by using political spaces to forge new rights. They are diverting norms of exclusion, making them more "friendly" to their interests. They are using norms that empower them in other domains to gain access to land.

This view is also supported by five case studies published in a book on women's land rights in East Africa (Adoko and Levine 2008; Ansoms and Holvoet 2008; Daley 2008; Englert 2008; Okuro 2008) demonstrating that "women in Eastern Africa are not powerless actors but find creative means to claim and ensure their rights to land" (Englert and Daley 2008, 3). Likewise, Kindi (2010) notes that although the post-war situation poses many challenges to women trying to access land, it also creates different opportunities to improve women's conditions. Following these lines of thought, we argue here that forum shopping between different legal institutions is one of the avenues that can be strategically used by women to enhance their land claims.

\section{Methods}

The data on which this article is based have been collected through a total of 12 months of fieldwork in the Acholi region, mainly in Gulu and Amuru districts. This data comes from a mix of methods. First, we interviewed 26 different actors who play a role in conflict resolution, including magistrates, lawyers, traditional chiefs (Clan Chiefs and Rwot KweriChiefs of the Hoe), Local Council members (LC) of various levels (LC1, LC2, LC3, LC5), Chief Administrative Officer (CAO), Resident District Commissioner (RDC), NGOs working on land issues in the Acholi Sub-Region of Northern Uganda, and paralegals trained by NGOs and working at village levels (the lowest administrative level in Uganda). 
Second, we selected (on a convenience sampling) and followed over time and space four cases on complex land conflicts involving women. All these cases were registered with a dispute resolution body. In addition, we tracked the path that the disputants undertook in and out of the different resolution fora in a bid to have their disputes resolved. We interviewed all stakeholders on all sides of the conflicts, including family members, neighbours, local leaders, lawyers, magistrates, paralegals, and NGO actors. For each of cases, we interviewed on average 10-20 people, depending on the number of people involved in the conflict.

We also conducted three focus group discussions. Two of these targeted 10-15 individuals each and included both men and women and other stakeholders involved in dispute resolution, generally at the local level. A third focus group discussion specifically targeted female participants. Finally, we went through the archives of the Amuru Magistrates Court over the past four years, and quantified key facts regarding land conflicts, such as the gender and age of plaintiffs and defendants, the type of conflict, and the outcome of court cases generally filed before the court. Our fieldwork was part of a research project on land conflicts in post-war Northern Uganda that has been financed by the Danish Development Agency (DANIDA).

\section{Statutory and customary approaches to gender and land tenure}

The Constitution of Uganda and the Land Act provide for equality between men and women with regard to access, ownership, and disposition of property before, during, and upon the dissolution of a marriage, and further provides that all customs that discriminate against women are null and void to the extent of its inconsistency (Articles 2, 33(5) C1995 Constitution of the Republic of Uganda; Section 27 Land Act, 1998). However, customary tenure holds that land in the Acholi sub-region is controlled by men through membership in a particular clan. The customary rationale given to exclude women from controlling land is that in a society practising clan exogamy and patrilocality, women usually marry outside of their home area and are expected to move to their husband's place. Women are expected to then gain land rights from their husbands' homes. Moreover, since children belong to the clan of their father, allowing daughters to inherit land on a par with their brothers would soon create a situation in which land is no longer controlled by clans but can pass from one clan to another with each new generation. In other words, placing men and women on an equal footing in controlling and inheriting land would be the end of the territorialisation of clans.

Women have dual identities as sisters in the families of origin and wives in their families by marriage. They have thereby customary land rights both through their father (or brothers) for those who have remained unmarried, or through their husband (or late husband's clan) for widows (Anying 2012, 19-24). The status of married women and their access to land in their husband's lineage is generally more secure when the full bride price has been paid at marriage and when they have given birth to children. But even women who are "not properly married" or women who have not produced any child can claim some customary rights over their "husband"s' land. As a rule, widows have the right to stay in their late husband's place and keep farming land in the name of their male children, who will inherit their father's land one day. If a widow does not wish to stay in her 
late husband's place (if she does not wish to be inherited by a member of her husband's clan, for example), or if a woman divorces, she normally goes back with her younger children to her father's place (her own clan), where she is given land to farm. But her children are supposed to go back to their father's place when they become adults in order to establish themselves in their own clan and farm their clan's land.

Thus, in this system, men have in theory more control over land, but women have in practice more opportunities than men to find land to farm, as they can access land through their husband/children, through their father/brother, or even through their mother/maternal uncle side. Male children, on their side, have fewer options than their mother, as they normally either access land through their father, or acquire new land by clearing vacant land. If they fail to do so, they might still access land through their mother's side, but such arrangement is usually seen as a temporary solution and is likely to bring conflicts if it continues. Polygamy, divorce, and remarriage render the negotiation of rights relatively complex, as half-siblings growing up in the same place might belong to different clans and have different rights.

Statutory and customary laws have a very different take on land and gender equality. Our data and observations from the field show that statutory and customary institutions also work in very different ways to resolve conflicts. First, the formal system makes judgements stating who is right and wrong and identifying a winner and a loser, while alternative fora do not have the power to pass judgement and can only do mediations that seek consensus and compromise acceptable to all parties (a situation that is confirmed by our field data, see also Stevens 2000). The fact that alternative fora generally lead to compromises tend to advantage people who claim land used by someone else, as claimants will usually gain (and defendants will lose) something in the process. Second, the formal system is expensive (the court fee is 90,000 shillings, plus fees for lawyers) and takes a long time to resolve conflicts. Our statistical data obtained from the land registry in Amuru District Court from 2012 to 2014 collected in September of 2014 indicates that out of the 149 cases filed between 2012 and 2014, only five judgements have been passed, and only after a period of at least 2 years.

The informal system, by contrast, is affordable to most and is quicker. The complainant just has to provide food and drinks, and pay for the transport of the people taking part in the mediation. The mediation meeting is organised relatively rapidly (within a few weeks, or two months at most) and is open to all, with many people participating (a few people from the local councils, some elders, witnesses, neighbours, possibly some participants from an NGO or other administrative institutions, and so on). When consensus is reached among this large number of prominent local actors, the case is considered solved and is backed up by all the people who participated in it. However, this resolution does not prevent parties of the conflicts to feel unjustly treated and to refuse the decision or bring their case to the formal justice system.

\section{Forum shopping in Northern Uganda}

Women (and men) involved in a land conflict can choose between many different avenues in order to bring their case. Five different types of institutions are involved in land dispute resolution in Northern Uganda: 
(1) Formal Court System: Dispute concerning customary land tenure may be filed before the Grade 1 Magistrate Court as a first court of instance of the respective geographical area in which the land in dispute is located. There is generally no pecuniary limitation. The judgment passed by the Magistrates Grade 1 Court may be appealed to the Chief Magistrates courts and thereafter to the High Court. The judgement made by any of these courts, unless otherwise appealed against, is enforceable as against the party whom the judgement has been passed by the party in whose favour the judgement was passed. Enforcement of judgement is usually a whole new process in itself, and can involve the police. The party seeking to enforce the judgment has to apply to the court to enforce the same.

(2) Traditional institutions: These are mandated by Section 88 (1) of the Land Act of 1998 to determine disputes over customary tenure, or act as a mediator between people who are in dispute over any matters arising out of customary tenure. The structural, procedural, and normative structure of this institution is not dictated by the state. Although there is no uniform composition and hierarchy of the traditional power structure in Acholi Sub-Region, it can be broadly sketched as a hierarchical structure ranging from the household level to the level of the chiefdom. At the hamlet level, we have the head of household, followed by the head of family (Won Paco), and then the "Chief of the Hoe" (Rwot Kweri, formally elected by the local community), a position created under the colonial administration. At the clan level, one finds the representative of the chief (Lawang Rwot), the clan head (Ladit Kaka), and finally, the clan chief (Rwot Moo), who is a member of the "royal clan" that dominates the region (Girling 1960). Disputants can bring a land case to any of these institutions or to several of them at the same time. Despite the hierarchy between traditional leaders, there is no appeal structure within the traditional institutions. Cases are transferred back and forth among the leaders. Disputants therefore have the possibility to begin at the lowest level, and gradually go higher up in the hierarchy if they are not satisfied with the outcome, or they can go to more than one of the leaders simultaneously. Unlike the decisions of the formal Magistrates Courts, the overriding principle in the dispute resolution is mediation that tries to reach a compromise based on restoring the relationship of the conflicting parties and promoting harmony in the clan and family (Anying 2012, 31). Further, there is no provision in the law that stipulates how the decision of the traditional leaders can be enforced. Enforcement is based purely on moral obligation and goodwill of the parties, and does not involve the police.

(3) Local council courts (LCC): The LCCs are established under the Local Council Court Act of 2006, which regulates in part their jurisdiction and mode of operation. The Local Council Court 1 is found at the village level, where the elected executive committee constitutes itself into a court to hear disputes. The Local Council Court 2 operates at the parish level and the Local Council Court 3 is found at the sub-county level. The local councillors are elected by the local community; they act as executive officers of the Local Council Committee and at the same time as (quasi) judicial officers of the Local Council Courts. The Court is constituted when five to eight members of the committee are present to hear a dispute. The procedures are simplified and the hearing is informal and conducted in indigenous languages. However, the Local Council Courts were declared illegitimate by the Constitutional Court in 2006, which effectively took away their mandate to legally sit as a court. Prior to 
their being declared illegitimate, they could, as a matter of law, pass judgements, which could be enforced, unless otherwise appealed to the chief magistrates courts. Today, LC courts continue to mediate land conflicts, but they can no longer pass legal judgement. In practice, however, disputants continue to follow the hierarchy in the LCC Courts, and make first instance calls at the LC1, and follow through to the hierarchy up to the LC3, although this process is no longer legal and is therefore informal. When they consult the next hierarchy, it is not an appeal, as they handle the same issues handled by the lower hierarchy.

(4) Elected and appointed government officials: a number of disputants consult Chief Administrative Officers (CAO), Resident District Commissioners (RDC), or chairpersons at the LC5 level to get help in their land conflict. The office of the Chief Administrative Officer is a government-appointed position based at the district level, at the subcounty level there is the Senior Principal Secretary, and the Community Development Officer at the parish level is the Parish Chief. The Local Council V is the political head of the district and is an elective position. The Resident District Commissioner, on his side, is a presidential appointee and represents the president in the District. These actors have no formal authority/jurisdiction to handle land disputes, but in the post-conflict Acholi sub-region have played an instrumental role in land conflict resolution. When approached, these actors participate primarily in mediations to try to settle land disputes amicably (Burke and Egaru 2011; Hopwood and Atkinson 2013). They do not pass judgement - they have no jurisdiction to do so - but people consult them because of their position of power and the authority that derives from it.

(5) NGOs also play a very instrumental role in land dispute resolution. In the post-conflict Acholi sub-region, a number of NGOs have sprung up and developed a mandate to handle land disputes by positioning themselves as an alternative forum. They provide general legal advice to parties in land disputes, but also conduct mediations and represent parties in court. Disputants consult NGOs as an alternative fora, although they also sometimes work together with the traditional institutions and the Local Council Courts. NGOs are also seen by the local population as a gateway to the formal system, because of the assistance they provide in the representation of parties before formal courts of law.

As the Figure 1 demonstrates, the choice that people have to make is not just between formality or informality, but between five different types of institutions, and between different institutions within each of the five types.

Forum shopping can be horizontal when it is possible to choose between different and parallel fora (such as the five types described above). It can also be horizontal when one can choose between several fora of a same type nested in a hierarchy, such as within the traditional authorities or within the LC court system (Helfer 1999; Unruh 2009). The formal system does not allow vertical forum shopping, because it applies the principle of res judicata, which means that the appellate court cannot deal with the same issues dealt with by a lower court. Forum shopping can be simultaneous when it is possible to bring one's case to different fora concurrently (either vertically, such as within the customary system, or horizontally between the five different systems). It can also be successive, when one must wait for the case to be judged in one forum before being able to bring it to another (such as appealing within the formal or LC court systems). 
1) Formal legal system Render judgements

\begin{tabular}{|l|}
\hline High court \\
\hline Chief magistrate \\
\hline Grade 1 magistrate \\
\hline
\end{tabular}

No vertical forum shopping (principle of res judicata)
2) Traditional authorities Conduct mediations

\begin{tabular}{|l|l|}
\hline Chief \\
\hline Clan head & \\
\hline $\begin{array}{l}\text { Chief of } \\
\text { the hoe }\end{array}$ & $\begin{array}{l}\text { Respected } \\
\text { elders }\end{array}$ \\
\cline { 1 - 1 } $\begin{array}{l}\text { Head of } \\
\text { the family }\end{array}$ & \\
\hline Head of household \\
\hline
\end{tabular}

Both simultaneous and/or successive vertical forum shopping (same issue, different bodies)
3) Local council courts Conduct mediations

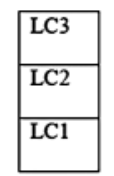

4) and 5) Other institutions: no official jurisdiction in land conflicts but provide help, legal advice, mediation, moral or political legitimacy
No simultaneous but successive vertical forum shopping (same issue, different bodies)

$\leftarrow$ Simultaneous horizontal forum shopping between the four different types of fora $\rightarrow$

Figure 1. Forum shopping and institutions involved in land conflict resolution.

The five kinds of fora found in Northern Uganda all deal with the same land issues, and do this concurrently, since a disputant can file a case before more than one dispute resolution body at the same time. The implication of this is that a disputant may file a case before the traditional institution, and before its conclusion, file the same case concurrently before the Magistrates courts. In addition, the disputant may also open up a case file with an NGO and even seek help based on the same issue and facts from an elected or appointed government office. This possibility is not only restricted to the plaintiff, it also extends to the defendant. For example, whereas the plaintiff may file a case before a traditional institution, a defendant may go ahead and file a case before a magistrate's court. Since forum shopping is unregulated and the two systems do not complement each other, both institutions may indeed make decisions on the same case. We will now discuss two concrete case studies that demonstrate how women can use the possibilities offered by forum shopping to claim land rights.

\section{Two cases on gender and forum shopping in Amuru}

\section{Case 1: Santa vs. Mwalim}

Lupwole had two sons, Oola and Akwilino (see Figure 2). Oola married Mariana and moved to his wife's birth place where he was given land by his in-laws. He brought with

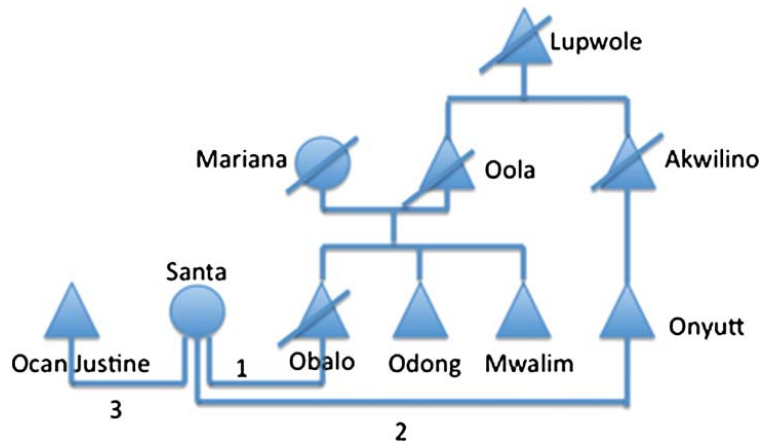

Figure 2. Kinship diagram of Santa and her in-laws. 
him his brother, Akwilino. Oola had nine children, including three sons called Obalo (the first-born), Odong, and Mwalim. Akwilino had several children, including a son called Onyutt. Obalo married Santa and had four children with her. After Obalo died in an Internally Displaced Person's (IDP) camp, Santa had a relationship with Onyutt, who was much younger than she was, and had a daughter with him. But Onyutt did not want to inherit Santa through levirate. Odong, who is now the legal heir of Oola's estate, did not want to inherit Santa either. Instead, Santa was inherited by Ocan Justine, a clan brother of her late husband, with whom she has four children.

Today, Santa has a conflict with her in-laws about where to farm and establish her homestead. At the end of the civil war, the children of Oola and Akwilino and their spouses and children all moved back to where they were before being displaced by the war in 1996. The family demarcated land for everyone, but Santa refused the land that was allocated to her and instead constructed her house on land that belonged to Mwalim. At the same time, Santa filed a case in the Local Council Court 1 against her in-laws, claiming that they had been accusing her of being a witch and were not allowing her to farm on land that used to belong to her husband. She also complained that the place that had been designated as the homestead was her garden before and during displacement. The local council enquired and did not find trace of witchcraft, and advised her to move her house and farm where she had been allocated land. Santa then asked for assistance from the Uganda Land Alliance (ULA), an NGO that provides legal advice and conducts mediations on land issues, claiming that her in-laws were farming on the fields that she used to farm with her husband. The NGO tried to mediate the conflict and agreed with the in-laws that they should not farm in her old fields (which they were not doing anyway), and they asked Santa to move her house where the head of the homestead (dog gang) had allocated her a place to stay. Still dissatisfied, Santa went to the clan head and claimed that her in-laws were abusing her and trying to chase her away. By the time the field notes of this case were compiled, the clan had not yet met.

When we talked privately to Santa, she brought other arguments to the table, such as the fact that there are graves on the land she has been allocated to build her house and that she does not want to live next to graves. She also claimed that Onyutt is building a house on the land where Santa used to live with her husband (which appears not to be true). Under the surface, it appears that Santa does not want to move her house, because she does not want to live too close to her in-laws and because she wants to live near the road (Amuru is being upgraded as a town, there is a lot of land speculation, and land adjacent to roads is the most valuable). Santa resents being under the authority of her brotherin-law, and would like to be the master of her own destiny. She would like Odong to demarcate land among the three brothers (Odong, Mwalim, and herself in the name of Obalo), and exclude all cousins (the children of Akwilino), who were also allocated land after the return from the camp. Prior to displacement, the children of Akwilino lived about 10 kilometers away, but occasionally farmed on the land in dispute. Santa also claims to be willing to exchange farm land with Mwalim, if he would allow her to stay where she is. She has built two extra houses on Mwalim's land since she brought the case to the LC1 and the NGO, despite having found no support whatsoever for her case - even her own children now prefer to live at their uncle's place.

When we talked with Santa's in-laws, the story took on another dimension. The in-laws claimed to have no conflict with her, to respect her highly as the first wife of the first-born 
of the family, the woman with the highest authority, and the one that knows all the farming boundaries. There is plenty of farming land, and they don't mind her farming another plot if she does not like the one she is farming now. They don't want to chase her away. On the contrary, they would like her to move closer to them, as they are part of the same family. This last point seems to be what is really at stake, and the traditional understanding of the extended family as united and solidary group under the leadership of the family's head is confronted by Santa's wish to decide for herself. They also explain Santa's reluctance to live with them by reference to her (rather shameful) liaison with Onyutt, and by the refusal of Odong to inherit her. The in-laws are amused by the fact that Santa always presents herself as a widow when the LC court or the NGO come to mediate the issue, although she is now married to Ocan Justine - there is a strong awareness nationally about the vulnerable position of widows. They also note that Santa always comes to Odong to find a solution when her children misbehave, but refuses his authority when he tries to encourage the family to collaborate and live together.

\section{Case 2: Sylvia vs. Lanyuru}

Sylvia married Acaye in 1979 and had six children with him. Acaye was a police officer and all the children are relatively well-off today. In the beginning of the 1990s, Acaye became sick and violent, and Sylvia's family came to remove her from her husband's place to bring her back to her pre-marital home. In 1993, Acaye committed suicide. In 2007, when people left the IDP camps, Sylvia did not want to go back to her parents' place, because accessing land there was complicated. She decided instead to come back to her dead husband's place. Her brothers-in-law refused to give her the piece of land that she was asking for, especially Lanyuru, the eldest surviving brother-in-law, who is also a member of the area land committee (responsible for demarcating land, solving land disputes, etc.).

Sylvia then built a house on her husband's land, but her house was burnt to the ground (allegedly by Lanyuru, although there was no proof and he was not convicted of any criminal offence). The Catholic Church allowed Sylva to build a hut on church land, while Sylvia reported her case to the police. The police talked to Lanyuru and asked him to let Sylvia stay and settle on her late husband's land. Her last-born son came from town to help her rebuild a permanent house, which is still in the process of being built.

But Lanyuru continued to ask her to leave and Sylvia reported the case to the council of elders (dogola). During the meeting, Lanyuru asked Sylvia to refund the bride price because she had abandoned her husband. The elders took Sylvia's side, and said that she did not have to refund bride price and could stay on her late husband's land. Still, Lanyuru continued to disturb Sylvia, claiming that she had killed her husband and was bringing witchcraft in the family. Sylvia went to the Rwot Kweri, but she did not pursue this procedure because she thought that the chief was not impartial (he was too closely related to Anyuru and too much on his side). Sylvia went to the Uganda Land Alliance (ULA) NGO to ask for help. Lanyuru, on his part, went to LC1 asking that the land be divided. A meeting was organised in which the ULA, the LC1, and the elders were present, and the land was divided. But only Acaye's land was divided, not Lanyuru's, which means that Lanyuru and Sylvia each gained control over half of Acaye's land in the process. Sylvia reluctantly accepted the decision, under pressure from her own children, who told her not to 
complain. Sylvia is now calling for a clan meeting to plant trees on the boundary between her and Lanyuru's land, to make sure that no one trespasses boundaries in the future. In the meantime, Sylvia has received extra farm land from another clan brother of her late husband. Despite having conflicts with Lanyuru, Sylvia still goes to him whenever she has a problem with one of her children, and he helps her solve this kind of problem. Lanyuru is also organising the wedding of Sylvia's daughter, and he will be getting the bride price as her father.

Sylvia thinks that the conflict she has with Lanyuru stems from the fact that he wanted to inherit her but that she refused to be inherited by him because he was like a child to her (her husband used to pay Lanyuru's school fees). She suspects that he is jealous because she had a relationship with another clan brother of her deceased husband and begat one child with him while she was living in IDP camps. She also suspects that Lanyuru accused her of witchcraft simply because he is interested in her late husband's land. The fact that her husband was better educated and had a good job in town probably added another dimension to the conflict, as villagers tend to consider that their brothers who have left the village to live and work in town have also left the land behind them for those who choose to remain in rural areas, which gives way to many conflicts.

Seen from Lanyuru's point of view, it is Sylvia who tried to grab land from him, not him trying to chase her away. He claims that she tried to grab land by force by building her house and farming on his land without asking him permission.

\section{Discussion}

A number of observations can be made from the two cases described above. First, in both cases, women succeed in securing long-term access to land in their late husbands' places, sometimes despite all odds (coming back after 20 years of absence, or grabbing land that did not belong to their husbands). The conflict is not so much about their right to access land in their husband's clan; rather, it is about the size and location of the land. The fact that Amuru is in the process of becoming a town, and that land speculation is rife, makes land size and location important aspects of these conflicts. Women want a slice of the speculative cake, and do not always end up losing, as Santa's case shows us.

Second, neither woman brought their case to the formal court system, but both brought their case to the Uganda Land Alliance NGO. NGOs are commonly seen as the gateway to the formal court system, but in both cases the NGO chose to organise mediations rather than take these women's cases to court. And in both cases, the women brought their cases to elders or LC1-3 at the same time as they asked for help from NGO, and continued doing so after the end of the mediation and after the NGO was out of the picture. Women play different cards in different systems. When talking to NGOs, they present themselves as vulnerable widows, as exemplified by Santa's case (widows receive a lot of attention from the national government and international donors). When dealing with heads of household, elders and LC courts, however, they present themselves as "wives of the clan", having acquired rights on clan land through marriage and by producing clan children, or because they are still married to a clan member through levirate.

Third, and most importantly in both cases, land conflicts are about much more than land. On the one hand, these conflicts are about marriage and clan identity. Women's access to land is always made through marriage into their husband's clan. Accessing land 
requires that they accept their duties of being a "wife of the clan", and conversely, the men they are in conflict with must fulfil their duties as heads of households. So, despite having land conflicts, or even social conflicts, men and women collaborate, for example, whenever men have to solve a problem or organise the wedding of the women's children. In both our cases, clan elders always supported the claim of widows to access clan land; the disagreement was more concerned with the location and size of the land. In these cases, land conflicts are not so much about access to land per se, as they are about finding the right balance of power between male heads of household or clan elders who are demanding respect for their authority over women, and women who want to gain independence from their in-laws and want to exert personal control over a piece of land.

On the other hand, land conflicts are also social conflicts. Old grudges, expressed through accusations of jealousy, murder or witchcraft, are never far away. People who dislike one another for some reason continue to be forced to live side-by-side as neighbours and in-laws. The geographical proximity of people transforms social conflicts into land conflict, since forcing an opponent to move away is the most radical type of solution to social conflicts. Data from other cases collected in our research show that a majority of land conflicts involving women originate in social conflicts between in-laws, cousins or co-wives. Whenever land conflicts are proxies of social conflicts, land issues cannot be solved unless social harmony is restored at the same time.

This last point is, in our view, one of the keys to understanding the forum shopping strategies deployed by women. Women who have a social conflict that translates into a land conflict know that solving their problem requires being accepted as a wife of the clan and finding some form of understanding and peace with the person with whom they are in conflict. They also know that if NGOs (or the formal court system) can help them in formally securing their rights to land, these decisions will not be accepted and enforced unless they find a solution to witchcraft accusations, to the shame they bear from past "misbehaviour", or to their position within the clan depending on their marital situation (e.g. whether bride price was paid or not, or whether they have produced children). NGOs and courts do not deal with these issues, even though they are at the core of social conflicts, which is why women always involve elders and LCs to find acceptable solutions to their social problems and thereby also to their land problems. Involving NGOs is an important leverage, because NGOs carry with them the implied threat to bring the case to court if it is not respecting the rights of women. But in fine, mediations rest on applying customary law rather than formal law, and women need the continuous support of elders to solve their social conflicts and to practically assert their rights on their husband's clan land.

\section{Conclusion}

In this article, we have argued that land conflicts involving women are often proxies of social conflicts and can therefore not be satisfactorily solved unless the social conflicts are solved at the same time. Since the formal system of justice and the NGOs that work as gateways to this system do not recognise the social dimension of land conflicts, the customary or informal institutions must fill the vacant space and have a major role to play in both land and social conflict resolution. Our research demonstrates that customary institutions play a major role in resolving land conflicts and that they can also work for the 
benefit of women. Forum shopping, including informal institutions, allows women to gather together a large number of local powerful actors to help them solve both their social and their land conflicts with quick and affordable mediations that reach compromises acceptable to all parties.

Interestingly, even NGOs, who are seen as the gateway to formal justice for those who cannot afford it, prefer mediations to formal court cases whenever possible. By carrying the threat that they would challenge in court any unjust compromise, with long delays and at a high financial cost for the opposing party, NGOs also provide a strong incentive to find a solution that is acceptable to all, at least when it comes to land. But as land conflicts are often proxies for social conflicts, women cannot be entirely satisfied with mediations that do not address the social causes of land conflicts, which explains why they continue to involve customary institutions even after mediations have been organised.

\section{Disclosure statement}

No potential conflict of interest was reported by the authors.

\section{Funding}

This work was supported by the Consultative Research Committee for Development Affairs (FFU) for Danish International Development Agency (DANIDA) [project number 12-056 AU].

\section{References}

Adoko, Judy, and Simon Levine. 2008. "Falling Between Two Stools. How Women's Land Rights are Lost between State \& Customary Law in Apac District, Northern Uganda.” In Women's Land Rights \& Privatization in Eastern Africa, edited by B. Englert and E. Daley, 101-120. Woodbridge: James Currey.

Adoko, Judy, and Simon Levine. 2009. "How can We Turn Legal Anarchy into Harmonious Pluralism? Why Integration is the Key to Legal Pluralism in Northern Uganda.", In Conference Packet, Customary Justice and Legal Pluralism in Post Conflict and Fragile Societies. Hosted by the United States Institute Of Peace George Washington University, World Bank, November 17-18.

Ansoms, A., and N. Holvoet. 2008. "Women \& Land Arrangements in Rwanda. A Gender-Based Analysis of Access to Natural Resources." In Women's Land Rights \& Privatization in Eastern Africa, edited by B. Englert and E. Daley, 138-175. Woodbridge: James Currey.

Anying, I. 2012. Re-Envisioning Gender Justice in Access and Use of Land Through Traditional Institutions: A Case for Customary Tenure of Land Ownership in Acholi Sub-Region, Northern Uganda. Copenhagen: Danish Institute for Human Rights https://menneskeret.dk/files/media/ dokumenter/udgivelser/irene_report_ok.pdf

Barnabas, O. D. 2013. “Tragedy of the Commons: From Victims of Lord's Resistance Army Conflict to Victims of Land Conflicts." Universal Journal of Education and General Studies 2(1): 15-20.

Barrera, A. 2015. Violence Against Women in Legally Plural Settings: Experiences and Lessons from the Andes. London: Routledge.

Basu, S. 2012. "Judges of Normality: Mediating Marriage in the Family Courts of Kolkata, India." Signs 37(2): 469-492.

Benda-Beckmann, F., and K. von Benda-Beckmann. 2010. "Multiple Embeddedness and Systemic Implications: Struggles over Natural Resources in Minangkabau since the Reformasi." Asian Journal of Social Science 38(2): 175-186.

Branch, A. 2007. Fostering the Transition in Acholiland: From War to Peace, from Camps to Home. Gulu: Human Rights Focus. 
Branch, A. 2008. "Gulu Town in War ... and Peace? Displacement, Humanitarianism and PostWar Crisis." Crisis States Working Paper Series No 2, Working Papers 36. London: London School of Economics.

Burke, Christopher., and Emiat Emmanuel Egaru. 2011. "Identification of Good Practices in Land Conflict Resolution In Acholi .” Kampala: United Nations Peace Building Program.

Chirayath, L., Sage, C., Woolcock, M. , 2005. Customary Law and Policy Reform: Engaging with the Plurality of Justice Systems.

Chopra, Tanja, and Deborah Isser. 2012. "Access to Justice and Legal Pluralism in Fragile States: The Case of Women's Rights." Hague Journal on the Rule of Law 4(2): 337-358.

Corradi, Giselle. 2011. "Access to Justice in Pemba City: How Exploring Women's Lived Realities with Plural Law Uncovers Programmatic Gaps.” The Journal of Legal Pluralism and Unofficial Law 43(64): 1-31.

Daley, E. 2008. "Gender, Uenyeji, Wealth, Confidence \& Land in Kinyanambo. The Impact of Commoditization, Rural-Urban Change \& Land Registration in Mufindi District, Tanzania." In Women's Land Rights \& Privatization in Eastern Africa, edited by B. Englert and E. Daley, 6182. Woodbridge: James Currey.

Dolan, C. 2009. Social Torture: The Case of Northern Uganda, 1986-2006. New York: Berghahn

Domingo, Pilar, and Tam O'Neil. 2014. The Politics of Legal Empowerment: Legal Mobilisation Strategies and Implications for Development. London: ODI Report. https://www.odi.org/sites/ odi.org.uk/files/odi-assets/publications-opinion-files/9008.pdf

Englert, B., and Daley, E. 2008. “Introduction: Women's Land Rights \& Privatization.” Women's Land Rights \& Privatization in Eastern Africa, edited by B. Englert and E. Daley, 1-17. Woodbridge: James Currey.

Englert, B. 2008. "Changing Land Rights \& Gendered Discourses. Examples from the Uluguru Mountains, Tanzania." In Women's Land Rights \& P rivatization in Eastern Africa, edited by B. Englert and E. Daley, 83-100. Woodbridge: James Currey.

Girling, F. K. 1960. The Acholi of Uganda. London: Her Majesty's Stationary Office.

Gray, L., and M. Kevane. 1999. "Diminished Access, Diverted Exclusion: Women and Land Tenure in Sub-Saharan Africa." African Studies Review 42(2): 15-39.

Griffiths, Anne. 1996. "Legal Pluralism in Africa: The Role of Gender and Women's Access to Law." PoLAR: Political and Legal Anthropology Review 19(2): 93-108.

Griffiths, John. 1986. "What is Legal Pluralism ?" The Journal of Legal Pluralism and Unofficial Law 24(18): 1-55.

Helfer, L. R. 1999. "Forum Shopping for Human Rights." University of Pennsylvania Law Review 148(2): 285-400.

Hellum, Anne. 2000. "Human Rights and Gender Relations in Postcolonial Africa: Options and Limits for the Subjects of Legal Pluralism." Law \& Social Inquiry 25(2): 635-655.

Hirsch, S. F. 1998. Pronouncing and Persevering: Gender and the Discourses of Disputing in an African Islamic Court. Chicago: University of Chicago Press.

Hopwood, J., and R. R. Atkinson. 2013. Land Conflict Monitoring and Mapping Tool for the Acholi Sub-region. Kampala: United Nations Uganda. http://www.lcmt.org/pdf/final_report.pdf

Juenger, F. K. 1988. "Forum Shopping, Domestic and International." Tulane Law Review 63: 553572.

Khadiagala, L. 2001. “The Failure of Popular Justice in Uganda: Local Councils and Women's Property Rights." Development and Change 32(1): 55-76.

Kindi, F. I. 2010. "Challenges and Opportunities for Women's Land Rights in Post-Conflict Northern Uganda.” MICROCON Research Working Papers 26. Accessed December 2 2015. http://www.glob alprotectioncluster.org/_assets/files/field_protection_clusters/Uganda/files/HLP\%20AoR/Uganda_ Challenges_and_Opportunities_for_Womens_Land_Rights_2010_EN.pdf.

Kobusingye, D. N., M. Van Leeuwen, and H. Van Dijk. 2016. "Where do I Report My Land Dispute? The Impact of Institutional Proliferation on Land Governance in Post-Conflict Northern Uganda." The Journal of Legal Pluralism and Unofficial Law 48(2): 238-255.

Leonardi, Cherry, Leben Nelson Moro, Martina Santschi, and Deborah H. Isser, 2010. Local Justice in Southern Sudan. Washington, DC: United States Institute for Peace. http://www.usip.org/pub lications/local-justice-in-southern-sudan 
Levine, S., and J. Adoko. 2006. "Land Rights and Displacement in Northern Uganda." Humanitarian Practice Network 34: 23-25. Accessed December 2 2015. http://odihpn.org/wp-content/ uploads/2006/07/humanitarianexchange034.pdf.

Martiniello, G. 2015. "Social Struggles in Uganda's Acholiland: Understanding Responses and Resistance to Amuru Sugar Works." Journal of Peasant Studies 42(3-4): 653-669.

Michaels, Ralf. 2009. "Global Legal Pluralism." Annual Review of Law and Social Sciences (5): 243262.

Moore, S. F. 1973. "Law and Social Change: The Semi-Autonomous Social Field as an Appropriate Subject of Study.” Law \& Society Review 7(4): 719-746.

Moore, S. F. 1978. Law as a Process, an Anthropology Approach. London: Routledge \& Kegan Paul.

Okuro, S. O. 2008. "Struggling with In-Laws \& Corruption in Kombewa Division, Kenya. The Impact of HIV/AIDS on Widows' and Orphans' Land Rights." In Women's Land Rights \& Privatization in Eastern Africa, edited by B. Englert and E. Daley, 121-137. Woodbridge: James Currey.

Rao, Nitya. 2007. "Custom and The Courts: Ensuring Women's Rights to Land, Jharkhand, India." Development and Change 38(2): 299-319.

Rouland, Norbert. 1994. Legal Anthropology. Palo Alto: Stanford University Press, Stanford.

Rugadya, M. A. 2008. Northern Uganda Land Study. Analysis of Post Conflict Land Policy and Land Administration: A Survey of IDP Return and Resettlement Issues and Lesson: Acholi and Lango Regions. Report for the World Bank. Accessed December 2 2015. http://www.landcoalition.org/ sites/default/files/documents/resources/northern_uganda_land_study_acholi_lango.pdf.

Spiertz, H.J.. 2000. “Water Rights and Legal Pluralism: Some Basics of a Legal Anthropological Approach.." In In Negotiating Water Rights, edited by B.R. Burns, R.S. Meinzen-Dick, 162200. New Delhi: Vistaar..

Stevens, J. 2000. Access to Justice in Sub-Saharan Africa: The Role of Traditional and Informal Justice Systems. London: Penal Reform International. http://www.gsdrc.org/docs/open/ssaj4.pdf

Stickler, M. 2012. Due Diligence on Lands at Risk of or Subject to Land Acquisitions in Uganda. Washington, DC: World Resource Institute and Africa Biodiversity Collaborative Group.

United Nations. 2013. Report of the Secretary General on the activities of the United Nations Regional Office for Central Africa and on the Lord's Resistance Army-affected areas. Document S/2013/297. Geneva: United Nations. Accessed December 1 2015. http://unoca.unmissions.org/Portals/unoca/ 4thUNSG\%20REPORT\%20ON\%20UNOCA\%20AND\%20ON\%20THE\%20LRA\%20-\%20MAY\% 202013.pdf.

Unruh, J. D. 2009. "Humanitarian Approaches to Conflict and Post-Conflict Legal Pluralism in Land Tenure." In Uncharted Territory, edited by Sara Pantuliano, 53-66. Colchester: Practical Action Publishing.

Vanderlinden, Jacques. 1989. "Return to Legal Pluralism: Twenty Years Later.” The Journal of Legal Pluralism and Unofficial Law 21(28): 149-157.

Wehrmann, B. 2008. Land Conflicts: A Practical Guide to Dealing with Land Disputes. Eschborn: GTZ. http://dlc.dlib.indiana.edu/dlc/handle/10535/5409.

Whyte, S., S. M. Babiiha, R. Mukyala, and L. Meinert. 2013. "Remaining Internally Displaced: Missing Links to Security in Northern Uganda." Journal of Refugee Studies 26(2): 283-301.

Whytock, Christopher A. 2010. “The Evolving Forum Shopping System.” Cornell Law Review 96: 481-534.

Wojkowska, Ewa. 2006. Doing Justice. How Informal Justice Systems Can Contribute. Oslo: United Nations Development Programme. http://www.democraciaejustica.org/cienciapolitica3/sites/ default/files/doingjusticeewawojkowska130307.pdf

Woodman Gordon, R. 1998. "Ideological Combat and Social Observation; Recent Debate about Legal Pluralism." Journal of Legal Pluralism and Unofficial Law 30(42): 21-59.

von Benda-Beckmann, K. 1981. "Forum Shopping and Shopping Forums: Dispute Processing in a Minangkabau Village in West Sumatra." The Journal of Legal Pluralism and Unofficial Law 13(19): 117-159.

"Why is Customary Protection Failing to Prevent Land Grabbing, 2009?" In Policy Brief 4, 1-4. Kampala: The Land and Equity Movement in Uganda. Accessed December 2 2015. http://landin-uganda.org/assets/Policybrief4-Why-is-customary-tenure-failing-to-prevent-land-grabbing26-9-2009.pdf. 